\title{
Sustainable Approach to Lake Restoration - An Innovative Treatment Applied in Polish Lakes
}

\author{
Renata Dondajewska-Pielka 1,*, Ryszard Gołdyn ${ }^{1}$, Agnieszka Budzyńska ${ }^{1}$, Katarzyna \\ Kowalczewska-Madura ${ }^{1}$, Anna Kozak ${ }^{1}$, Beata Messyasz ${ }^{2}$, Stanisław Podsiadłowski ${ }^{3}$ \\ ${ }^{1}$ Department of Water Protection, Faculty of Biology, Adam Mickiewicz University; rgold@amu.edu.pl (R.G.) \\ ${ }^{2}$ Department of Hydrobiology, Faculty of Biology, Adam Mickiewicz University; messyasz@amu.edu.pl \\ ${ }^{3}$ Department of Biosystem Engineering, Faculty of Environmental and Mechanical Engineering, Poznan \\ University of Life Sciences; stapod@up.poznan.pl \\ * Correspondence: gawronek@amu.edu.pl; Tel.: +48-61-829-5880
}

\begin{abstract}
A sustainable strategy, involving a combination of physical, chemical and biological methods was proposed as an innovative approach to lake restoration in Poland. We believe that: (i) the interference with the lake shall be limited to the extent that is necessary for the gradual reconstruction of the ecosystem; (ii) attention must be paid to the preservation of biodiversity as an important element affecting the adaptation of the ecosystem in the face of change; and (iii) restoration requires less invasive methods (in comparison with eg. sediment dredging) and naturebased solutions. In the sustainable approach combined methods are used simultaneously, i.e. physical (hypolimnion aeration by means of wind-driven aerator), chemical (phosphorus and ammonium $\mathrm{N}$ precipitation with small doses of compounds) and biological methods (supportive stocking with the fry of predatory species). Another innovative method is the direction of spring waters containing high concentration of nitrates to the deoxygenated bottom of the lake. This method increased the redox potential in the sediment-water interface, preventing the release of phosphorus from the bottom to the water column. It should be stressed that all methods are cost effective compared to other methods of restoration, what is of paramount importance for the local administration, being usually sponsors of lake restoration in Poland.
\end{abstract}

Keywords: lake restoration; nutrients; phytoplankton; sustainability

\section{Introduction}

Sustainable lake restoration is defined as the simultaneous application of several pro-ecological, non-aggressive methods, preventing the creation of feedback mechanisms in the ecosystem. The inactivation of phosphorus in the water column using small doses of magnesium chloride or iron sulphate (less that $15 \mathrm{~kg} \mathrm{ha}^{-1}$ ) is the key method used in this approach. Chemicals are dosed with the use of mobile pulverizing aerator (so called MAP) in the amount adjusted to the current phosphorus concentration in the lake [1]. The distribution of doses over the vegetation season creates a constant pressure on phytoplankton community, resulting in its gradual reconstruction and, above all, the reduction of cyanobacteria biomass. This bottom-up pressure is strengthened by top-down impact [2], coming from biological method of restoration - the biomanipulation, leading to changes in fish fauna structure by increasing the quantity of predatory fish. Finally, both methods are supported by water aeration, implemented in this sustainable approach by means of wind-drived aerator for hypolimnetic water aeration [3]. The improvement of oxygen conditions enables the phosphorus binding in the bottom sediment and has a positive effect on the habitat of the organisms inhabiting the lake, including fish and macroinvertebrates.

Another innovative method is the direction of spring waters containing high concentration of nitrates to the deoxygenated bottom of the lake. This method increases the redox potential in the sediment-water interface, preventing the release of phosphorus from the bottom to the water column. Nitrate treatment significantly affects the metabolism of the lake by boosting the activity of 
ubiquitous bacteria at the sediment surface, resulting in the reduction of oxygen uptake by sediments, formation of hydrogen sulphide and increased phosphorus binding [4]. Moreover, nitrates are characterized by higher solubility in water in comparison to oxygen as well as the ability to penetrate into the sediment $[5,6]$. We have proposed the utilization of nitrates already present in the lake catchment, coming from fertilizers used on agricultural areas instead of usually used solid chemical e.g. calcium nitrate [6, 7] or nitrate embedded in a matrix of Fe/Al hydroxide [8].

This type of approach is part of the so-called nature-based solutions, i.e. solutions aimed at gradual reconstruction of the structure and functioning of the ecosystem without the need to take too deeply intervening actions. Such restoration should be adapted to local conditions, and above all, it should aim at maintaining biodiversity as an important factor influencing the adaptation of the ecosystem to the changes induced in it $[9,10]$. Additionally, sustainable restoration costs are spread over time, being more acceptable for local authorities, who usually reimburse it in Poland.

\section{Combined restoration of deep Durowskie Lake}

Lake Durowskie is a dimictic, flow-through, postglacial ribbon-type lake situated in Western Poland $\left(17^{\circ} 12^{\prime} 11^{\prime E} \mathrm{E}, 52^{\circ} 49^{\prime} 6^{\prime \prime} \mathrm{N}\right)$. The lake surface area is $143 \mathrm{ha}$, maximum depth $14.6 \mathrm{~m}$, mean depth $4.6 \mathrm{~m}$ and volume 11,322,900 $\mathrm{m}^{3}$ [11]. Progressive eutrophication of Durowskie Lake was observed at the turn of $20^{\text {th }}$ and $21^{\text {st }}$ century, with summer water blooms dominated by cyanobacteria, mainly Limnothrix redekei (Goor) Meffert and Planktothrix agardhii (Gomont) Anagnostidis \& Komárek [12], low transparency (minimally $0.7 \mathrm{~m}$ in 2008), oxygen depletion and the presence of hydrogen sulphide in deeper layers of the water column.

A sustainable restoration was begun in 2009 by means of three methods: (i) phosphorus inactivation in the water column using low doses of iron sulphate and magnesium chloride, dosed by mobile pulverizing aerator (ii) hypolimnetic water aeration with the use of two wind-driven aerators, and (iii) biomanipulation, based on pike and pikeperch fry stocking (Fig. 1). The small doses of iron sulphate (4-15 $\left.\mathrm{kg} \mathrm{ha}^{-1}\right)$, applied 3-5 times during vegetation season, inactivated orthophosphates in the water column but did not coagulate the suspended solids. Stocking with predatory fish took place at the end of May with 'fingerlings, and it was conducted with variable number of fry [13].

Phosphorus inactivation together with water aeration enhance each other's impact on water quality, resulting in a decrease of orthophosphates and ammonium nitrogen concentrations in the course of 11 years of restoration. The transformations of nitrogen compounds in hypolimnion were determined by variability of oxygen content - when it was low, ammonium $\mathrm{N}$ was undergoing nitrification, and then denitrification, leading to the total depletion of nitrates accompanying a reduction of ammonium $\mathrm{N}$. As the oxygen level increased, the role of nitrification was greater as well, and nitrate concentrations were higher. Due to its paramount importance for redox potential positive values in sediment-water interphase, orthophosphates were successfully bounded onto iron compounds, dosing during P inactivation [9]. 


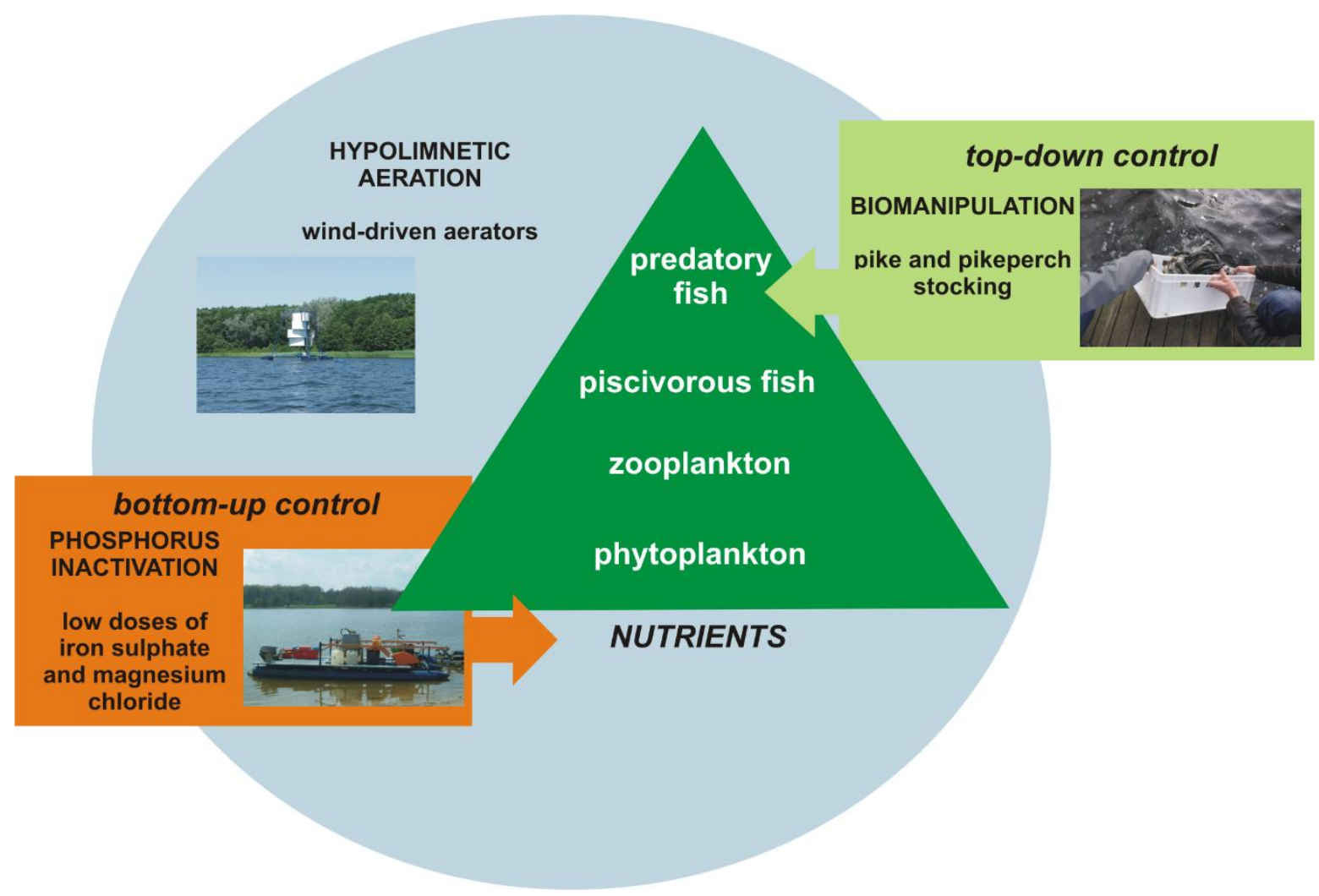

Figure 1. Methods used in the sustainable restoration of Durowskie Lake (photo by: R. DondajewskaPielka, K.Kowalczewska-Madura, R. Gołdyn).

This comprehensive approach was supported by biomanipulation, exerting impact on phytoplankton structure, manifested as a reduction of its biomass as well as lower chlorophyll-a content (from $\mathrm{ca} 60 \mathrm{mg} \mathrm{m}^{-3}$ prior the restoration to $9-14 \mathrm{mg} \mathrm{m}^{-3}$ after 10 years) and higher water transparency ( $2 \mathrm{~m}$ on average). Cyanobacteria were replaced by diatoms, dinoflagellates and chrysophytes, and macrophytes both submerged and nymphaeids (especially Potamogeton perfoliatus L.) increased covered area due to higher water transparency [11, 14].

Expected changes were also noted in the matter of internal $\mathrm{P}$ loading due to increased accumulation in sediments as well as lower amount of organic matter depositing on its surface and increased oxygen content at the bottom [11, 15].

\section{Innovative restoration of Uzarzewskie Lake}

Uzarzewskie Lake $\left(52^{\circ} 27^{\prime} \mathrm{N}, 17^{\circ} 08^{\prime} \mathrm{E}\right)$ is a small, postglacial, kettle-shape lake in Western Poland, with surface area of 10.6 ha, maximum depth $7.3 \mathrm{~m}$ and mean depth $3.4 \mathrm{~m}$ [16]. It is a hypereutrophic, dimictic and bradymictic lake with a thick layer of bottom sediments, which supplied the lake with a high internal load of nutrients [15, 17, 18]. High phosphorus concentrations in water column resulted in phytoplankton proliferation, manifested in very high chlorophyll-a content (up to $170 \mathrm{mg}$ $\left.\mathrm{m}^{-3}\right)$ as well as low water transparency (0.45 m minimally). Cyanobacteria, including Cuspidothrix issatschenkoi (Usachev) P.Rajaniemi, Komárek, R.Willame, P.Hrouzek, K.Kastovská, L.Hoffmann \& K.Sivonen, Dolichospermum spiroides (Klebhan) Wacklin, L.Hoffmann \& Komárek, and Planktothrix aghardii dominated in the phytoplankton [19, 20].

Due to intense phosphorus release form sediments, its inactivation with small doses of iron sulphate was started in 2006. Mobile pulverizing aerator dosed the coagulant 6 times in 2006 and 3 times in 2007 in an amount ranging from 60 to $70 \mathrm{~kg}$ (380 kg and $180 \mathrm{~kg}$ in total, respectively). Although the internal loading has been diminished by $41 \%$ [17], water quality improvement was not so clear. Water transparency increased, nevertheless cyanobacterial blooms were still observed, with Planktothrix agardhii and Limnothrix redekei domination [19, 21]. 
The main issue was oxygen depletion in hypolimnion, preventing the permanent phosphorus accumulation in sediments on iron hydroxides. Nitrate treatment was selected as a method enabling to create proper conditions for phosphorus binding. This method significantly affects the metabolism of the lake by boosting the activity of ubiquitous bacteria at the sediment surface, resulting in the reduction of oxygen uptake by sediments, formation of hydrogen sulphide and increased phosphorus binding [4]. Moreover, nitrates are characterized by higher solubility in water in comparison to oxygen as well as the ability to penetrate the sediment $[5,6]$. We have proposed the utilization of nitrates already present in the lake catchment, coming from fertilizers used on agricultural areas instead of usually used solid chemical e.g. calcium nitrate (Riplox/Limnox method [7]) or nitrate embedded in a matrix of Fe/Al hydroxide (Depox method [8]). In 2008 two watercourses flowing from the springs $\left(9.5^{\circ} \mathrm{C}, 11.5 \mathrm{mgO}_{2} \mathrm{l}^{-1}\right.$ and $36.9 \mathrm{mgN}-\mathrm{NO}_{3}$, on average $)$ were directed towards the hypolimnion (Fig. 2) in order to improve water oxygenation and to raise the redox potential of the bottom sediments.

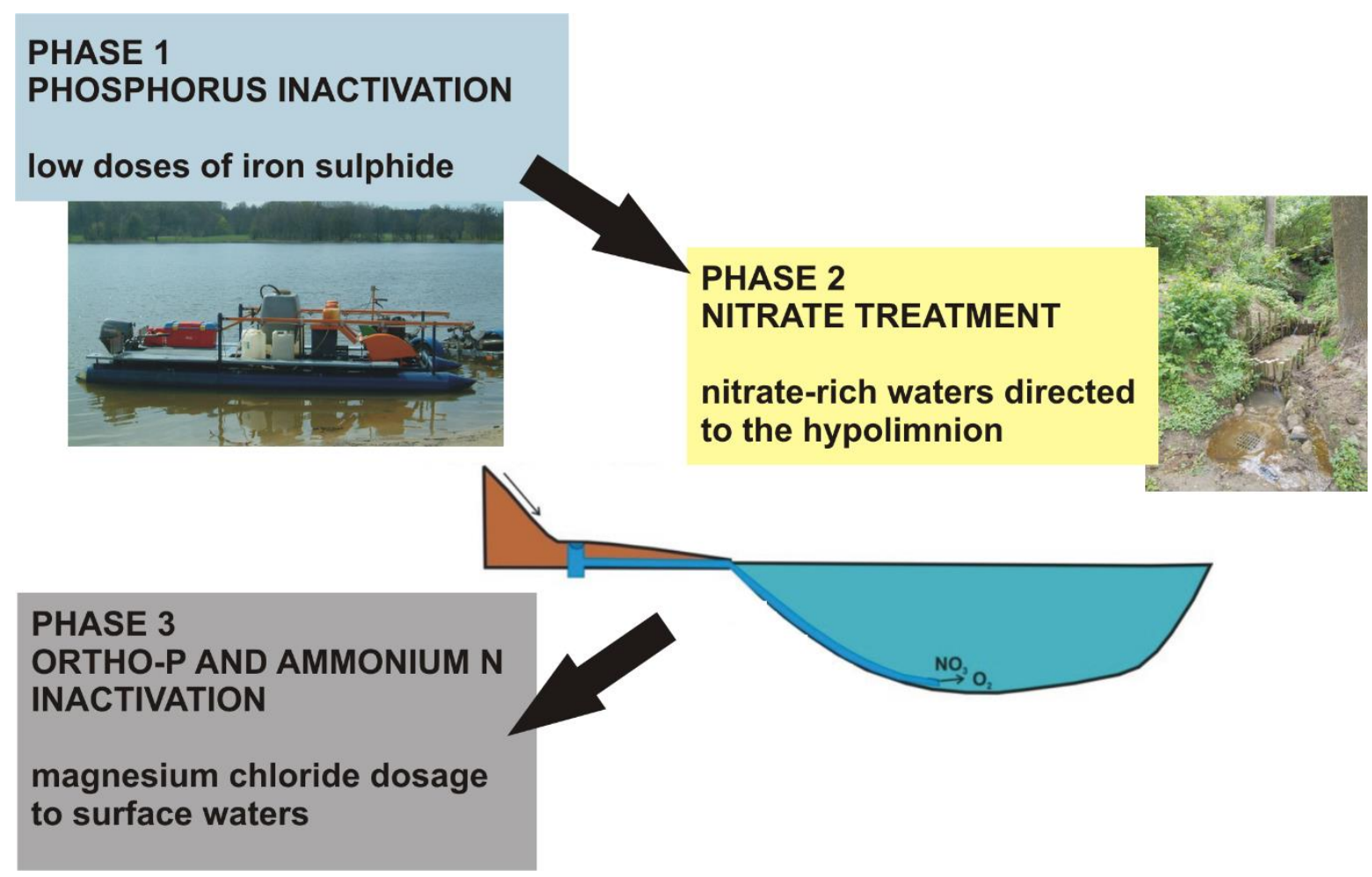

Figure 2. The three phases of Uzarzewskie Lake restoration (photo by: K. Kowalczewska-Madura, R. Dondajewska-Pielka).

As we expected, phosphorus concentrations were significantly reduced in water column [21], mainly due to 10 times lower internal P loading from lake sediments [11,15]. This phenomenon was possible as denitrification, being the key process of nitrogen compounds transformation in hypolimnion, prevents the reduction of $\mathrm{Fe}^{3+}$ to $\mathrm{Fe}^{2+}$. As the nitrate treatment covers the deepest part of the lake, there was a need for additional treatments related to surface waters. Magnesium chloride has been dosed via small inflow in the amount of $25 \mathrm{~kg}$ per month since 2017, aiming at the precipitation of both orthophosphates and ammonium $\mathrm{N}$ [10]. As a consequence of simultaneous reduction of those mineral forms of nutrients cyanobacteria biomass was diminished [22], especially in case of Dolichospermum flos-aquae, Planktothrix agardhii and Limnothrix redekei.

\section{Conclusions}

The sustainable lake restoration, regardless of the specifics of the measures undertaken and the method used, affects both the physical and chemical characteristics of the lake water and the elements of the trophic chain, which interacts with the functioning of the lake ecosystem. Multiannual research 
revealed that simultaneous application of several methods, which prevents feedback mechanisms, increases the efficiency of restoration. Moreover, this approach is easy to use, energy-efficient and not as expensive as other, more aggressive methods. It is of paramount importance in countries in which the funding for lake restoration is limited, as it is in Poland, and it is usually reimbursed by local authorities.

Author Contributions: R.D-P. wrote the paper, R.G., A.B., K.K-M., A.K., B.M., S.P. corrected the paper

Acknowledgments: This work was partially supported by The Polish Science Centre (research project No. NN305 372838).

Conflicts of Interest: The authors declare no conflict of interest.

\section{References}

1. Podsiadłowski, S. Method of precise phosphorus inactivation in lake waters. Limnol Rev 2008, 8,1-2: 51-56

2. Taylor, J.M.; Vanni, M.J.; Flecker A.S. Top-down and bottom-up interactions in freshwater ecosystems: emerging complexities. In Trophic ecology: bottom-up and top-down interactions across aquatic and terrestrial systems; Hanley, T.C., La Pierre, K.J., Eds.; Cambridge University Press, 2015, pp. 55-85

3. Podsiadłowski, S.; Osuch, E.; Przybył, J.; Osuch, A.; Buchwald, T. Pulverizing aerator in the process of lake restoration, Ecol Eng 2018, 121: 99-103, doi: 10.1016/j.ecoleng.2017.06.032

4. Søndergaard, M.; Wolter, K-D.; Ripl, W. Chemical treatment of water and sediments with special reference to lakes. In Handbook of ecological restoration; Perow, M.R.; Davy, A.J. Eds.; Cambridge University Press, 2002: 184-205

5. Hansen, J.; Reitzel, K.; Jensen, H.S.; Andersen, F. Ø. Effects of aluminum, iron, oxygen and nitrate additions on phosphorus release from the sediment of a Danish softwater lake, Hydrobiologia 2003, 492: 139-149, doi: 10.1023/A:1024826131327

6. Klapper, H. Technologies for lake restoration, Papers from Bolsena Conference (2002). Residence time in lakes: Science, Management, Education. J. Limnol. 62 (Suppl. 1), 2003: 73-90

7. Ripl, W. Biochemical oxidation of polluted lake sediment with nitrate - a new restoration method. Ambio 1976, 5: 132-135

8. Deppe, T.; Benndorf, J. Phosphorus reduction in a shallow hypereutrophic reservoir by in-lake dosage of ferrous iron, Wat Res 2002, 36 (18): 4525-4534, doi: 10.1016/s0043-1354(02)00193-8

9. Dondajewska, R.; Kowalczewska-Madura, K.; Gołdyn, R.; Kozak, A.; Messyasz, B.; Cerbin, S. Long-term water quality changes as a result of s sustainable restoration - a case study of dimictic Lake Durowskie, Water 2019, 11: 616, doi: 10.3390/w11030616

10. Dondajewska, R.; Gołdyn, R.; Kowalczewska-Madura, K.; Kozak, A.; Romanowicz-Brzozowska, W.; Rosińska, J.; Budzyńska, A.; Podsiadłowski, S. Hypertrophic lakes and the results of their restoration in Western Poland. In The Handbook of Environmental Chemistry. Polish River Basins and Lakes - Part II: Biological Status and Water Management, Korzeniewska, E.; Harnisz, M. Eds.; Springer International Publishing, 2020, 373-399, doi: 10.1007/978-3-030-12139-6

11. Kowalczewska-Madura, K.; Dondajewska, R.; Gołdyn, R.; Kozak, A.; Messyasz, B. Internal phosphorus loading from bottom sediments of a dimictic lake during its sustainable restoration. Wat Air Soil Pollut 2018, 229: 280

12. Gołdyn, R.; Messyasz, B. The water quality and restoration possibilities of Lake Durowskie, Faculty of Biology, Adam Mickiewicz University, 2008, report in Polish

13. Gołdyn, R.; Podsiadłowski, S.; Dondajewska, R.; Kozak, A. The sustainable restoration of lakes-towards the challenges of the Water Framework Directive. Ecohydrology \& Hydrobiology 2014, 14, 68-74, https://doi.org/10.1016/j.ecohyd.2013.12.001

14. Gołdyn, R.; Messyasz, B.; Domek, P.; Windhorst, W.; Hugenschmidt, C.; Nicoara, M.; Plavan, G. The response of Lake Durowskie ecosystem to restoration measures, Carpathian Journal of Earth and Environmental Sciences 2013, 8,3: 43-48

15. Kowalczewska-Madura, K.; Dondajewska, R.; Gołdyn, R. Internal phosphorus loading in eutrophic lakes in Western Poland. In The Handbook of Environmental Chemistry. Polish River Basins and Lakes - Part I: Hydrology and Hydrochemistry, Korzeniewska, E.; Harnisz, M. Eds.; Springer International Publishing, 2020, 277-303, doi: 10.1007/978-3-030-12123-5 
16. Kozak, A.; Gołdyn, R.; Variation in phyto- and zooplankton of restored Lake Uzarzewskie, Pol J Env Stud 2014, 23 4: 1201-1209

17. Kowalczewska-Madura, K.; Dondajewska, R.; Gołdyn, R. Influence of iron treatment on phosphorus internal loading from bottom sediments of the restored lake. Limnol Rev 2008 8, 4: 177-182

18. Kowalczewska-Madura, K.; Gołdyn, R.; Dondajewska, R. The bottom sediments of Lake Uzarzewskie - a phosphorus source or sink?, Ocean Hydrobiol Stud 2010, 39, 3: 81-91, doi: 10.2478/v10009-010-0042-4

19. Budzyńska, A.; Gołdyn, R.; Zagajewski, P.; Dondajewska, R.; Kowalczewska-Madura, K. The dynamics of Planktothrix agardhii population in shallow dimictic lake, Ocean Hydrobiol Stud 200933 (Suppl. 2): 7-12

20. Gołdyn, R.; Kowalczewska-Madura, K.; Dondajewska, R.; Budzyńska, A.; Domek, P.; Romanowicz, W. Functioning of hypertrophic Uzarzewskie Lake ecosystem. Proceedings of the $12^{\text {th }}$ World Lake Conference Taal 2007, Jaipur, 2007: 200

21. Dondajewska, R.; Kozak, A.; Kowalczewska-Madura, K.; Budzyńska, A.; Gołdyn, R.; Podsiadłowski, S.; Tomkowiak, A. The response of a shallow hypertrophic lake to innovative restoration measures Uzarzewskie Lake case study, Ecol Eng 2018, 121: 77-82, doi: 10.1016/j.ecoleng.2017.07.010

22. Kozak, A.; Budzyńska, A.; Dondajewska-Pielka, R.; Kowalczewska-Madura, K.; Gołdyn, R. Functional groups of phytoplankton and their relationships with environmental factors in the restored Uzarzewskie Lake. Water 2020, 12: 313, doi: 10.3390/w12020313

(C) 2020 by the authors; licensee MDPI, Basel, Switzerland. This article is an open access article distributed under the terms and conditions of the Creative Commons by Attribution (CC-BY) license (http://creativecommons.org/licenses/by/4.0/). 